\title{
A Procedure for Smooth Implementation of Activity Based Costing in Small Companies
}

\author{
Narcyz Roztocki \\ State University of New York at New Paltz / Department of Business Administration \\ 75 South Manheim Boulevard, New Paltz, NY 12561 \\ 914-257-2930 (phone); 914-257-2947 (fax) \\ roztockn@matrix.newpaltz.edu \\ Jorge F. Valenzuela \\ José D. Porter \\ Robin M. Monk \\ Kim LaScola Needy \\ University of Pittsburgh / Department of Industrial Engineering \\ 1041 Benedum Hall, Pittsburgh, PA 15261 \\ 412-624-9838 (phone); 412-624-9831 (fax) \\ kneedy@engrng.pitt.edu
}

\begin{abstract}
This paper describes a procedure that allows small companies to smoothly switch from a traditional costing system to an Activity Based Costing system at low risk and with minimal investment. The paper focuses on any type of small company (less than 100 employees) for which the standard implementation of Activity Based Costing is too expensive and complex. The implementation guide leads a company step-by-step through Cooper's two-stage activity based cost system model. The complete implementation procedure consists of eight major steps. At first, decision-makers choose among three methods, educated guess, systematic appraisal, or actual data collection, for obtaining cost information. At this stage, the decision-makers determine the level of accuracy that is needed and the amount of money to be assigned to this project. Next, the overhead expenses such as administration, rent, utilities, and transportation are compiled into product cost information using newly developed matrices. Using these matrices, cost related calculations are simplified and thus the overhead costs are easily traced to the cost objects in the final step. The easy-of-use of the proposed procedure is illustrated using actual data from a small tool \& die manufacturing company.
\end{abstract}

\section{Keywords}

Activity-Based Costing, Small Business

\section{Introduction}

Manufacturing firms face ever-increasing competition in today's global marketplace. Companies must react quickly and manufacture high quality, low cost products to be successful in this new environment. To make proper decisions, senior managers must have accurate and up-todate costing information. Traditional costing systems based on volume-based allocation of overhead have lost relevance in a manufacturing environment that has seen a sharp increase in overhead and a subsequent decline in direct labor. These traditional costing systems tend to distort product costs and lead to poor strategic decisionmaking (Johnson and Kaplan, 1987; Johnson, 1987; 1991).

One innovative costing method designed to deal with the deficiencies of traditional costing systems is Activity Based Costing (ABC). ABC, pioneered by Robin Cooper, Robert Kaplan, and H. Thomas Johnson (Cooper, 1988a; 1988b; 1990; Cooper and Kaplan, 1988; Johnson, 1990), is a costing methodology used to trace overhead costs directly to cost objects, i.e., products, processes, services, or customers and help managers to make the right decisions regarding product mix and competitive strategies. According to Turney, $\mathrm{ABC}$ can radically change how managers determine the mix of their product line, price their products, identify the location for sourcing components, and assess new technology (Turney, 1989). Although the literature has reported numerous implementations of $\mathrm{ABC}$ in large manufacturing firms, there has been limited accounting of $\mathrm{ABC}$ being embraced by small manufacturing firms (less than 100 employees) (Needy and Bidanda, 1995; Bharara and Lee, 1996). Upon closer examination, there appears to be several factors preventing small manufacturing firms from implementing an $\mathrm{ABC}$ costing system including lack of data, technical resources, financial resources, and adequate computerization. Perhaps the main obstacle, lack of data, centers on the problem of collecting and processing the needed data in the correct format at a reasonable cost. Because the information needed for $\mathrm{ABC}$ is costly and small manufacturing firms are typically constrained financially, these companies need to be very selective in the type of data and analysis that they use to determine overhead costs. Moreover, small businesses operate uniquely, a condition referred to as resource poverty, that requires specialized cost management approaches (Welsh and White, 1981). Thus, a methodology that will enable a small company to obtain accurate product cost information yet minimize financial effort is needed. 
Exhibit 1. Relationship among expense categories, activities, and products.

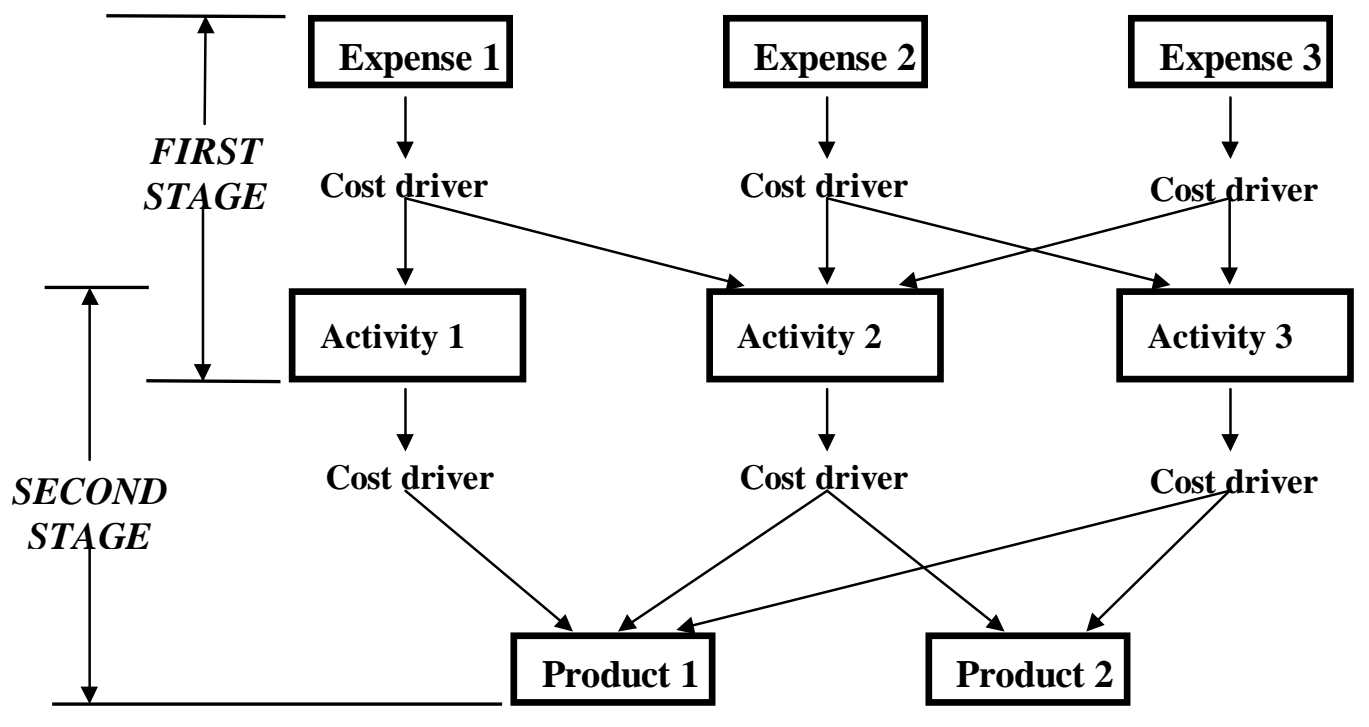

In this paper, an efficient and inexpensive method for implementing $\mathrm{ABC}$ in small business environments is proposed. This procedure systematically provides the decision-maker with accurate cost information to establish corporate strategies, determine product cost, and improve the cost structure.

\section{Activity Based Costing}

Cooper describes two stages in the ABC model (Cooper, 1987a; Cooper, 1987b). In the first stage, costs are assigned to cost pools within an activity center, based on a cost driver. There is no equivalent step in a traditional costing approach. In the second stage, costs are allocated from the cost pools to a product based on the product's consumption of the activities. This stage is similar to a traditional costing approach except that the traditional approach uses solely volume related characteristics of the product without consideration for non-volume related characteristics. Some examples of cost drivers not related to volume include setup hours, number of setups, ordering hours, and number of orders. Allocating non-volume related costs using volume-based methods distorts the product costs.

\section{Methodology}

In the ABC model, overhead expense categories such as administration, rent, transportation, and insurance are identified. This cost data can be obtained easily from accounting. The next step is to determine the main activities that simplify the tracing of cost information. This can be accomplished by grouping actions into activities and activities (or cost pools) into activity centers using the $\mathrm{ABC}$ approach. Some examples of activities for a small manufacturing company are receiving a customer inquiry, customer quotes, production supervision, and shipping products. Expenses are going to be assigned to the previously defined activities via the first stage cost drivers. Following the second stage, activity cost drivers are determined to allocate overhead to individual products. Exhibit 1 illustrates the hierarchical relationship among expense categories, activities, and products.

The proposed methodology assumes that the overhead cost and its categorization are available, generally from accounting. Expense categories refer to the traditional way in which a company divides manufacturing overhead. This information will assist the company in validating that the total overhead calculated at the beginning of the process matches the total obtained when summing the overhead that is assigned to each individual product using $\mathrm{ABC}$.

\section{Identifying activities or cost pools}

In order to implement $\mathrm{ABC}$, the complete business process should be divided into a set of activities. A flowchart of the process is a commonly used tool for identifying these main activities. Each box represents activities and arrows denote the flow of the system. Thus, in order to establish the needed activities for $A B C$, homogeneous processes must be grouped together. In other words, product driven activities and customer driven activities must be separated in order to establish two individual homogeneous activities. Examples of activities for manufacturing companies are quote preparation, production supervision, and material handling.

\section{Activities and first stage cost drivers}

Once the main activities have been defined, a total cost of each activity can be calculated. First, the expense categories related to each activity are identified. For example, the activity cost for "quote preparation" includes costs from various expense categories such as salary, rent, utility, and office supplies. To properly trace the expenses to each activity, cost drivers, also called first stage cost drivers, have to be identified for each expense category. For instance, the expense category "rent" associated with the activity "quote preparation" may be driven by square 
feet, whereas, the expense category "salary" may be driven by the amount of time the employee spends on this activity.

\section{Second Stage Cost Drivers}

In the second stage, activities are traced to products using second stage cost drivers. As with first stage cost drivers, data needed for second stage drivers may not be readily available to represent the proportion of cost pools that correspond to the products. For instance, mileage can be difficult to trace to individual product. In the absence of actual data there becomes a need to estimate the amount of activity cost consumed by each product.

\section{Information Gathering Procedures}

Gathering information is essential in order to achieve accuracy of final product costs. An important part of the required data is the proportions needed in each stage of an ABC costing system. Each activity consumes a portion of an expense category. Similarly, each product consumes a portion of an activity. As discussed previously, a proportion usually represents this portion. For instance, the activity "quote preparation" consumes 0.1 (10\%) of administration expenses. There are many ways to obtain these proportions and the selected procedure will impact the desired accuracy. Three levels of data accuracy can be used in estimating these proportions: educated guess, systematic appraisal, and collection of real data.

\section{Educated guess}

In the case where real data can not be obtained or data collection efforts can not be financially justified, an educated guess can be made in order to obtain proportions. These guesses should be done collaboratively by management, financial organizers, and operational employees associated with the costing center of interest. This team can provide an educated guess of the proportions of costs allocated in both stages of an $\mathrm{ABC}$ costing methodology. The level of accuracy obtained is based on a combination of the teams' diversity and their knowledge of the cost center of interest.

\section{Systematic Appraisal}

A more scientific way to obtain the proportions for tracing costs is using a systematic technique such as Analytic Hierarchical Process (AHP) (Saaty, 1982; Golden, Wasil, and Harker, 1989). AHP is a suitable tool for pulling subjective individual opinion into more representative information. For example, assuming that the allocation of a gasoline expense is needed between three cost pools namely sales, delivery and maintenance. By questioning the departments that consume this resource and by asking them to evaluate what percentage of mileage they accumulate in a certain period of time, AHP can generate the percentage of this expense and allocate it to the appropriate cost pool.

A second area in which AHP can be used is to allocate the expense from the cost pool to each individual product. At this step it is important to determine an appropriate cost driver in order to achieve the desired level of accuracy. For example, suppose we wish to trace the sales cost pool to each product. One approach is to estimate the level of sales activity needed for each of the individual products. Let assume the following scenario: a company produces five products. Product A is a very well established product requiring minimal effort from the sales representatives when they talk to potential consumers. On the other hand, products B, C and D are in the middle of their life cycle. Finally, product $\mathrm{E}$, is a new product that consumes a lot of time from the sales representatives. Instead of allocating an equal amount of sales expenses to each one of the products, AHP can provide an estimation that can allow the company to more accurately trace this cost to the products. The methodology followed by AHP requires first determining factors that account for cost relationship between activities and products. In this specific illustration, locations of travel for sales and time spent with the client discussing each individual product may be some examples of these factors. Secondly, the sales representative assigns a ranking among products according to the distance needed to support them. A second raking among products is established in proportion to the time spent with the customer. Finally, the subjective rankings of sales representatives are combined by AHP and ratios for sales expenditure among the five products are obtained.

\section{Actual data collection}

The most accurate and most costly procedure for computing proportions is the collection of real data. In most cases, a data collection procedure must be developed and data collection equipment may need to be purchased. Moreover, collection of the data will need to be timely and skilled collectors may be required. The results often have to be analyzed using statistical methods. For example, job sampling can be used to estimate the time proportion dedicated to supervise the manufacturing of a particular product. In this case, the supervising engineer is asked, at random time intervals, to specify the product being currently supervised. Based on this data the needed information can be obtained.

\section{Proposed procedure for tracing overhead expenses to cost objects}

\section{Step 1. Get the expense categories}

The initial step is to examine the expense categories included in the income statement of the company.

Step 2. Identify main activities

Step 2 can be performed in parallel with Step 1.

Step 3. Relate expenses to activities by establishing an EAD matrix.

In this step, the activities that contribute to each expense are identified and the Expense-Activity-Dependence 
(EAD) matrix is created. The expense categories represent the columns of the EAD matrix, whereas the activities identified in Step 2 represent the rows. If the activity $i$ contributes to the expense category $j$, a checkmark is placed in the cell $i, j$.

Step 4. Replace check-marks by proportions in the EAD matrix.

Each cell that contains a check-mark is replaced by a proportion which is estimated using any of the procedures previously mentioned. Each column of the EAD matrix must add up to 1 .

Step 5. Obtain dollar values of activities.

To obtain the dollar values of each activity the following equation is applied.

$$
\operatorname{TCA}(\mathrm{i})=\sum_{\mathrm{j}=1}^{\mathrm{M}} \operatorname{Expense}(\mathrm{j}) \times \operatorname{EAD}(\mathrm{i}, \mathrm{j})
$$

Where:

$T C A(i)=$ Total cost of activity $\mathrm{i}$

$M=$ number of expense categories

Expense $(j)=$ Dollar value of expense category $\mathrm{j}$

$\operatorname{EAD}(i, j)=$ Entry $\mathrm{i}, \mathrm{j}$ of Expense-Activity-

Dependence matrix

Step 6. Relate activities to products by establishing an APD matrix.

In this step, the activities consumed by each product are identified and the Activity-Product-Dependence (APD) matrix is created. The activities represent the columns of the APD matrix, whereas the products represent the rows. If the product $i$ consumes the activity $j$, a check-mark is placed on the cell $i, j$.

Step 7. Replace check-marks by proportions in the APD matrix.

Each cell that contains a check-mark is replaced by a proportion which is estimated using any of the procedures previously mentioned. Each column of the APD matrix must add up to 1 .

Step 8. Obtain dollar values of products.

To obtain the dollar values of each product the following equation is applied.

$$
\operatorname{OCP}(\mathrm{i})=\sum_{\mathrm{j}=1}^{\mathrm{N}} \mathrm{TCA}(\mathrm{j}) \times \operatorname{APD}(\mathrm{i}, \mathrm{j})
$$

Where:

$O C P(i)=$ Overhead cost of product $\mathrm{i}$

$N=$ Number of activities

$T C A(j)=$ Dollar value of activity $\mathrm{j}$

$A P D(i, j)=$ Entry $\mathrm{i}, \mathrm{j}$ of Activity-Product-

Dependence matrix

The procedure described can be easily implemented using common standard spreadsheet software.

\section{Application Example}

In this section the overhead costs of a typical small manufacturing firm are traced using the proposed methodology. The example uses the average of actual costs tabulated from several small-manufacturing companies to represent the costs of a 'typical' small business enterprise. Moreover, this approach also preserves the anonymity of the companies.

Tool \& Die Inc. is a small manufacturing company in Western Pennsylvania that manufactures three main products and supplies to multiple customers. Ongoing engineering work is prominent because of the use of CNC machines to manufacture products. Ten main customers are responsible for more than 80 percent of the total business. Since its foundation 20 years ago, the Tool \& Die Inc. has growth by adding three to five new employees per year. Currently, its total work force is nearly one hundred employees. Despite the growth in company size and business volume, the profitability has declined during the last few years. In the last two years, the company experienced losses for the first time in its history. Management believes that costing by intuition or by applying traditional methods is no longer appropriate. Therefore, they decided to introduce an ABC costing system to the company. Because the data required for the $\mathrm{ABC}$ system does not already exist and the cost to collect all of it would be prohibitive for this firm, management decided to use educated guesses, systematic appraisal, and actual data.

The initial step was to examine the expense categories included in the income statement of Average Inc and to select cost drivers. Exhibit 2 shows this breakdown. In the second step, Tool \& Die Inc. identified its main activities and their respective second stage cost drivers as shown in Exhibit 3. Exhibit 4 illustrates a hierarchical tree relating expense categories, activities and products. The third step determined which activities contributed to each expense category. For example, the activities contributing to the expense category "Transport" are material receiving and product shipment. 
Exhibit 2. Expense categories and their respective cost drivers

\begin{tabular}{|l|c|l|}
\hline Expense category & Cost $(\$)$ & Cost drivers \\
\hline Administration & 270,000 & Time (hours) \\
\hline Depreciation & 180,000 & Dollar use of resources $(\$)$ \\
\hline Rent and utilities & 150,000 & Space $\left(\mathrm{ft}^{2}\right)$ \\
\hline Office expenses & 70,000 & Level of use of office resources $(\%)$ \\
\hline Transport & 50,000 & Distance (miles) \\
\hline Interest & 45,000 & Cost of the activity (\$) \\
\hline Product shipment & 45,000 & Weight $($ Lb) \\
\hline Business travel & 45,000 & Distance (miles) \\
\hline Business insurance and legal expenses & 40,000 & Cost of resource used by the activity $(\$)$ \\
\hline Advertising & 40,000 & Level of benefit $(\%)$ \\
\hline Entertainment & 20,000 & Level of importance of customer $(\%)$ \\
\hline Miscellaneous expenses & 45,000 & None \\
\hline
\end{tabular}

Exhibit 3. Main activities and their second stage cost drivers

\begin{tabular}{|l|l|}
\hline Activity & Cost driver \\
\hline Customer contact & Number of customer contacts \\
\hline Quote preparation & Number of quotes \\
\hline Engineering work & Engineering hour \\
\hline Material purchasing & Number of purchase orders \\
\hline Production preparation & Number of production runs \\
\hline Material receiving and handling & Number of receptions \\
\hline Production management and supervision & Product complexity \\
\hline Quality assurance & Product complexity \\
\hline Product shipping & Distance \\
\hline Customer payment administration & Number of payments \\
\hline General management and administration & Intensity of activities \\
\hline
\end{tabular}

Exhibit 4. Expense categories (hierarchical tree)

\section{Overhead Allocation}

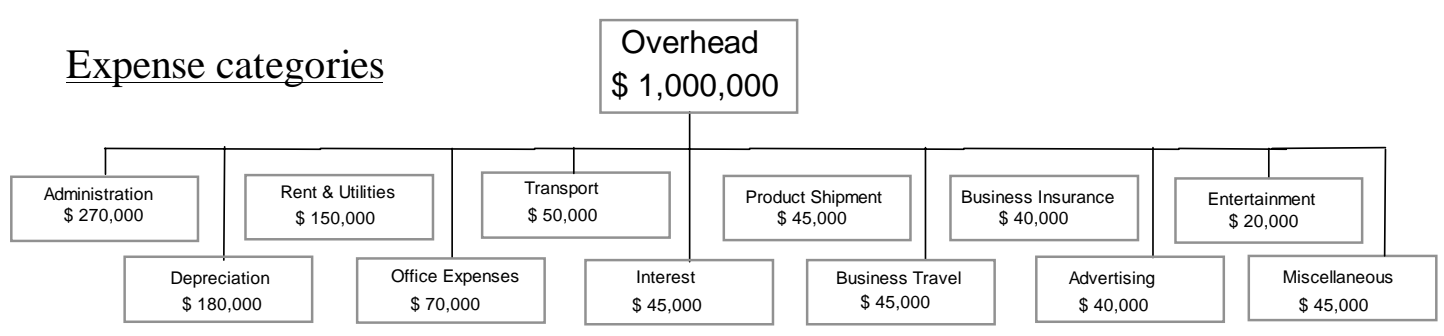

$\underline{\text { Activities }}$

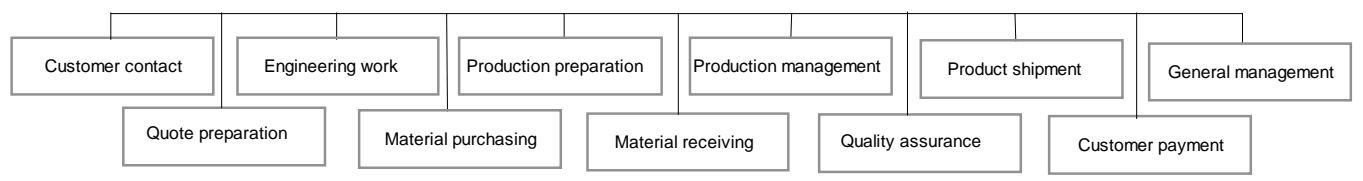

Products

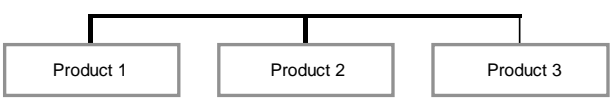


Exhibit 5. Expense-Activity-Dependence (EAD) matrix

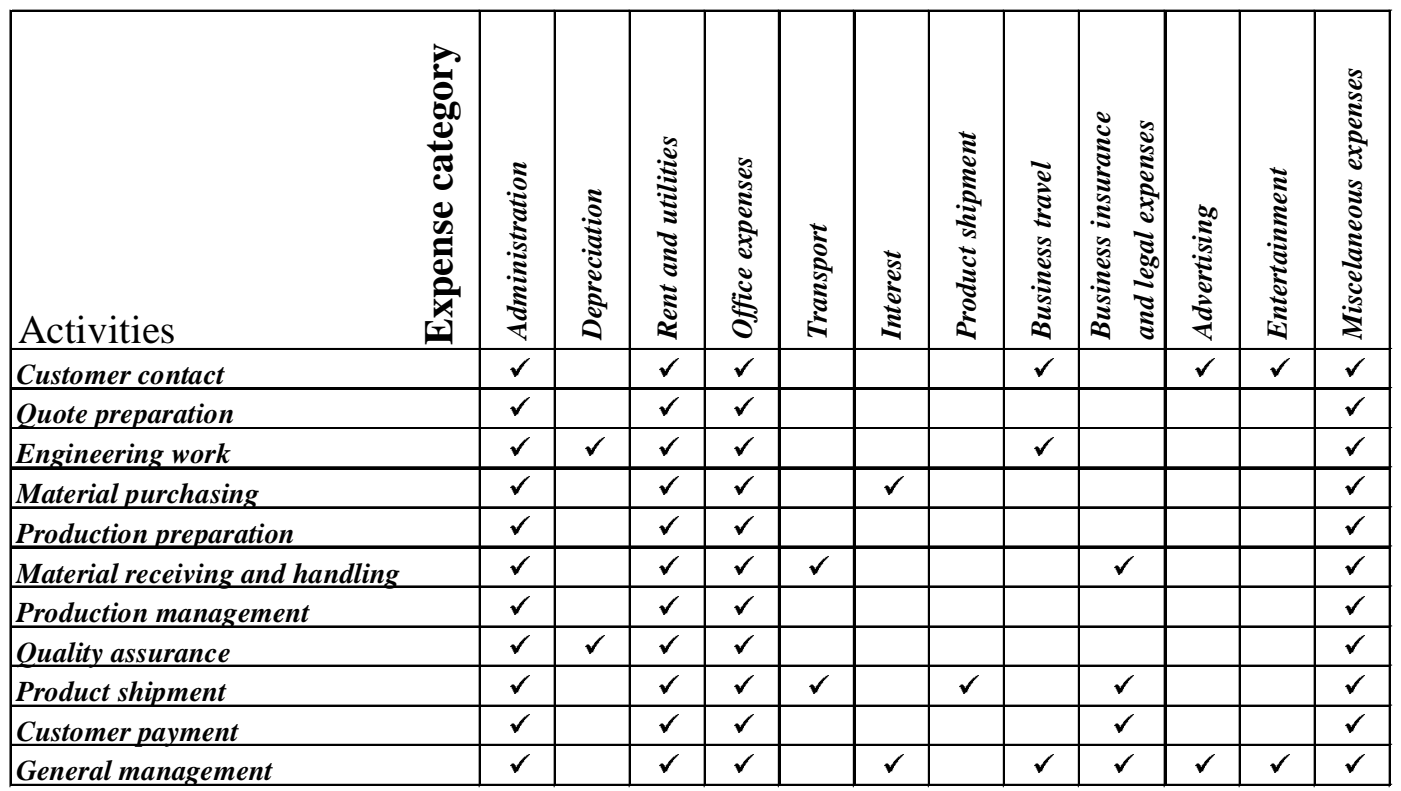

Exhibit 6. Expense-Activity-Dependence (EAD) matrix

\begin{tabular}{|c|c|c|c|c|c|c|c|c|c|c|c|c|c|}
\hline Activities & 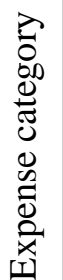 & 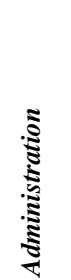 & 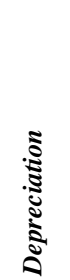 & 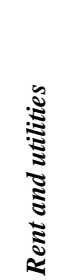 & 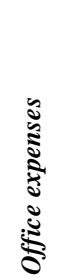 & है & $\stackrel{\bar{气}}{\Xi}$ & 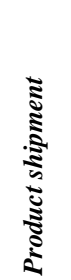 & 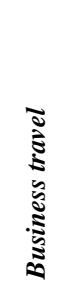 & 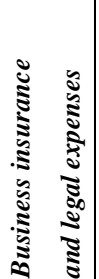 & 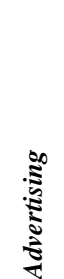 & 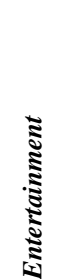 & 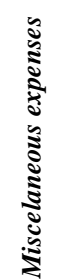 \\
\hline Customer contact & & 0.06 & & 0.01 & 0.24 & & & & 0.63 & & 0.64 & 0.58 & 0.09 \\
\hline Quote preparation & & 0.10 & & 0.05 & 0.14 & & & & & & & & 0.09 \\
\hline Engineering work & & 0.10 & 0.70 & 0.12 & 0.08 & & & & 0.14 & & & & 0.09 \\
\hline Material purchasing & & 0.08 & & 0.09 & 0.09 & & 0.80 & & & & & & 0.09 \\
\hline Production preparation & & 0.04 & & 0.11 & 0.03 & & & & & & & & 0.09 \\
\hline Material receiving and handling & & 0.05 & & 0.09 & 0.06 & 0.40 & & & & 0.11 & & & 0.09 \\
\hline Production management & & 0.20 & & 0.13 & 0.01 & & & & & & & & 0.09 \\
\hline Quality assurance & & 0.10 & 0.30 & 0.20 & 0.02 & & & & & & & & 0.09 \\
\hline Product shipment & & 0.05 & & 0.12 & 0.05 & 0.60 & & 1.00 & & 0.23 & & & 0.09 \\
\hline Customer payment & & 0.04 & & 0.01 & 0.08 & & & & & 0.46 & & & 0.09 \\
\hline General management & & 0.18 & & 0.07 & 0.20 & & 0.20 & & 0.23 & 0.20 & 0.36 & 0.42 & 0.09 \\
\hline
\end{tabular}

To systematically describe the contribution of activities to expense categories, the Expense Activity Dependence (EAD) matrix was used. The EAD matrix for Tool \& Die Inc. is shown in Exhibit 5. A " $\checkmark$ " at the entry $i, j$ denotes that the activity $i$ generates expense in category j.

In step four, the costs of each expense category are traced to activities. Each expense category is divided among activities according to the proportion of contribution. For instance, the expense category "Transport" is divided into two activities (material receiving and product shipment), and the ratio of contribution is 0.4 and 0.6 , respectively. In this case, 0.4 and 0.6 as shown in Exhibit 6 replaces the corresponding check marks of the EAD matrix. Note that each column will sum to one, implying that the entire expense category is spread across the activities. The ratios presented in Exhibit 6 were obtained by using the three procedures described previously: actual data, systematic appraisal (AHP), and educated guesses. When data was available the ratios were determined according to the first stage cost driver. For instance, Tool \& Die Inc. tracked the miles consumed by the activities material receiving and handling and product shipment (miles is the first stage cost driver for "Transport"). The records showed that 40,000 miles and 60,000 miles were consumed by material receiving and handling and product shipment, respectively. Accordingly, the ratios for the expense category "Transport" were 0.4 and 0.6. 
On the other hand, Tool \& Die Inc. did not keep track of the distance for business travel (distance is the first stage cost driver for the category expense "Business travel"). The activities that cause business travel expenses were customer contact, engineering work and general management. In this situation the ratios were estimated using AHP. Employees at Tool \& Die Inc. involved in these three activities were asked to estimate the relative distance (cost driver) used by each activity. For example, the following three questions were asked:

- How was the total distance traveled due to customer contact compared with engineering work?

- How was the total distance traveled due to customer contact compared with general management?

- How was the total distance traveled due to engineering work compared with general management?

The answers to these questions were translated into numbers using the scale measurement table shown in Exhibit 7, and then they were input into the software package Expert Choice (Expert Choice is a decision support software developed and distributed by Expert Choice, Inc.) to estimate the ratios.

Exhibit 7. Scale measurement table

\begin{tabular}{|c|l|}
\hline Numerical values & \multicolumn{1}{|c|}{ Definition } \\
\hline 1 & Equally important \\
\hline 3 & Slightly more important \\
\hline 5 & Strongly more important \\
\hline 7 & Very strongly more important \\
\hline 9 & Extremely more important \\
\hline $2,4,6,8$ & Intermediate values \\
\hline
\end{tabular}

In step five, every entry $i, j$ of the EAD matrix was replaced with the resulting dollar value by multiplying the cost of the expense category $j$ and the ratio $\mathrm{i}, \mathrm{j}$. The new matrix gives the dollar resource consumption of each activity. The total cost for each activity was obtained by adding each row. Exhibit 8 depicts the new EAD matrix for Tool \& Die Inc. with the resulting dollar resource consumption of each activity.

In step six, activity costs were traced to each product after the total cost of each activity was determined. The procedure is similar to the one used for tracing cost in the first stage; however, second stage cost drivers allowed Tool \& Die Inc. to determine or estimate activity consumption by product. In this stage the APD matrix is used. The APD matrix for Tool \& Die Inc. is shown in Exhibit 9. In a similar fashion, a " $\checkmark$ " at the entry i,j denotes that product i consumes activity j.

In step seven, the check marks were replaced by the corresponding ratios.

As before, the ratios were calculated using educated guess, systematic appraisal (AHP), and actual data. For example, the three products consume the activity material purchasing. To estimate the appropriate ratios, the employees involved in production were asked the relative number of purchase orders (cost driver for material purchasing) required for each product. The following questions were asked to obtain information needed for AHP:

- How was the total number of material purchase orders for product 1 compared with product 2 ?

- How was the total number of material purchase orders for product 1 compared with product 3 ?

- How was the total number of material purchase orders for product 2 compared with product 3 ?

The ratios were then placed into the APD matrix, as shown in Exhibit 10. In step 8, the overhead costs for each product was computed. The resulting APD matrix, shown in Exhibit 11, gives the total overhead costs for each product as well as their origin.

\section{Conclusion}

The implementation of a new cost system involves investment in time and money. A cost system based on $\mathrm{ABC}$ requires organizational changes, employee acceptance, investment in software and hardware, equipment for data collection, and so on. Although, ABC has been successfully used in many large companies it does not guarantee a payback in a short period of time. By using the proposed method for implementing an $\mathrm{ABC}$ costing system, the risk of switching from a traditional costing system to an extensive $\mathrm{ABC}$ system can be reduced significantly. The proposed method is more suitable for smaller companies because it provides a smooth transition from a traditional costing system to $\mathrm{ABC}$, it does not require a high investment in sophisticated data collection systems, and it does not require a serious organizational restructuring. Therefore, the proposed method can be used as an intermediate step for gradually implementing a full $\mathrm{ABC}$ system where the estimated data is replaced by actual data. In addition, the EAD and APD matrices assist in the comprehension of how overhead costs are generated. These matrices can also be used for recognizing improvement opportunities. As a future step a software package based on this methodology can be developed that would trace overhead cost to products accurately, at low cost, and in short time. 


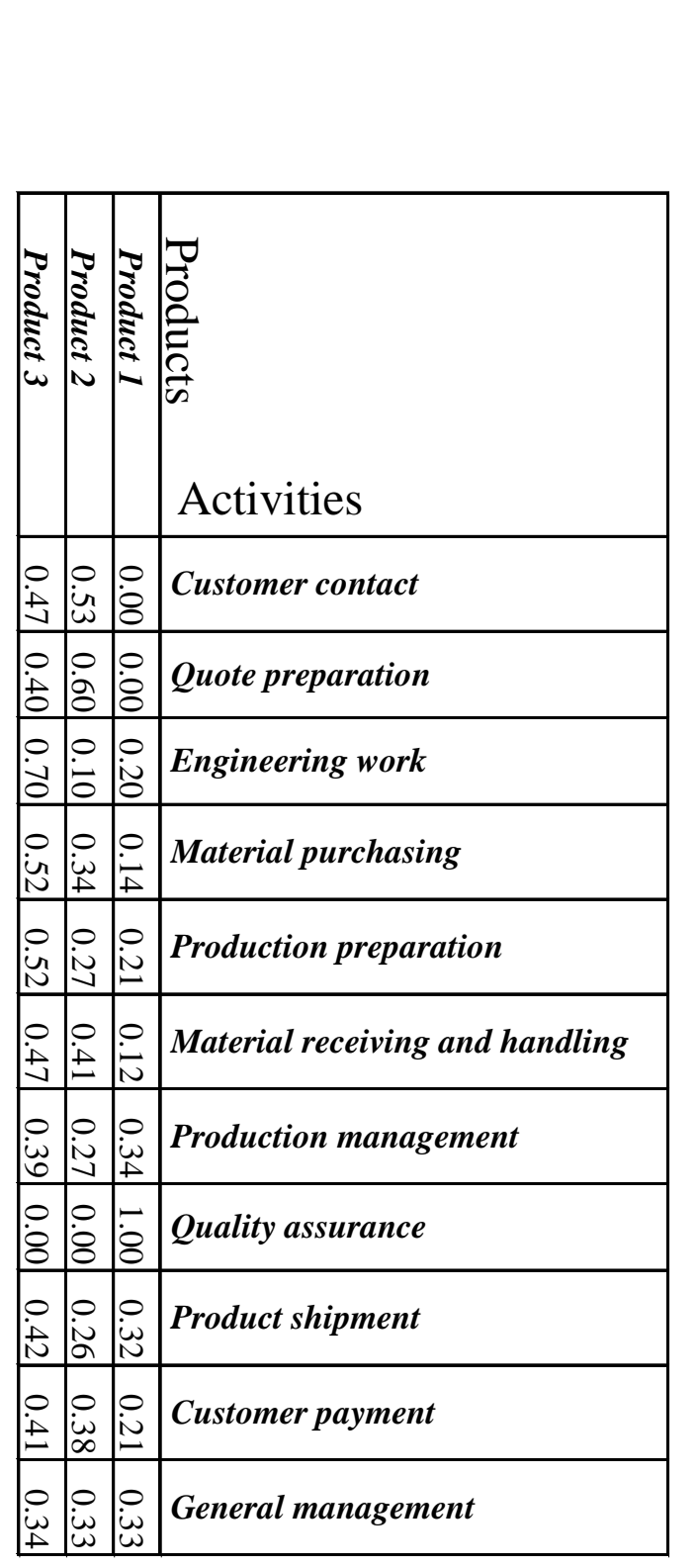

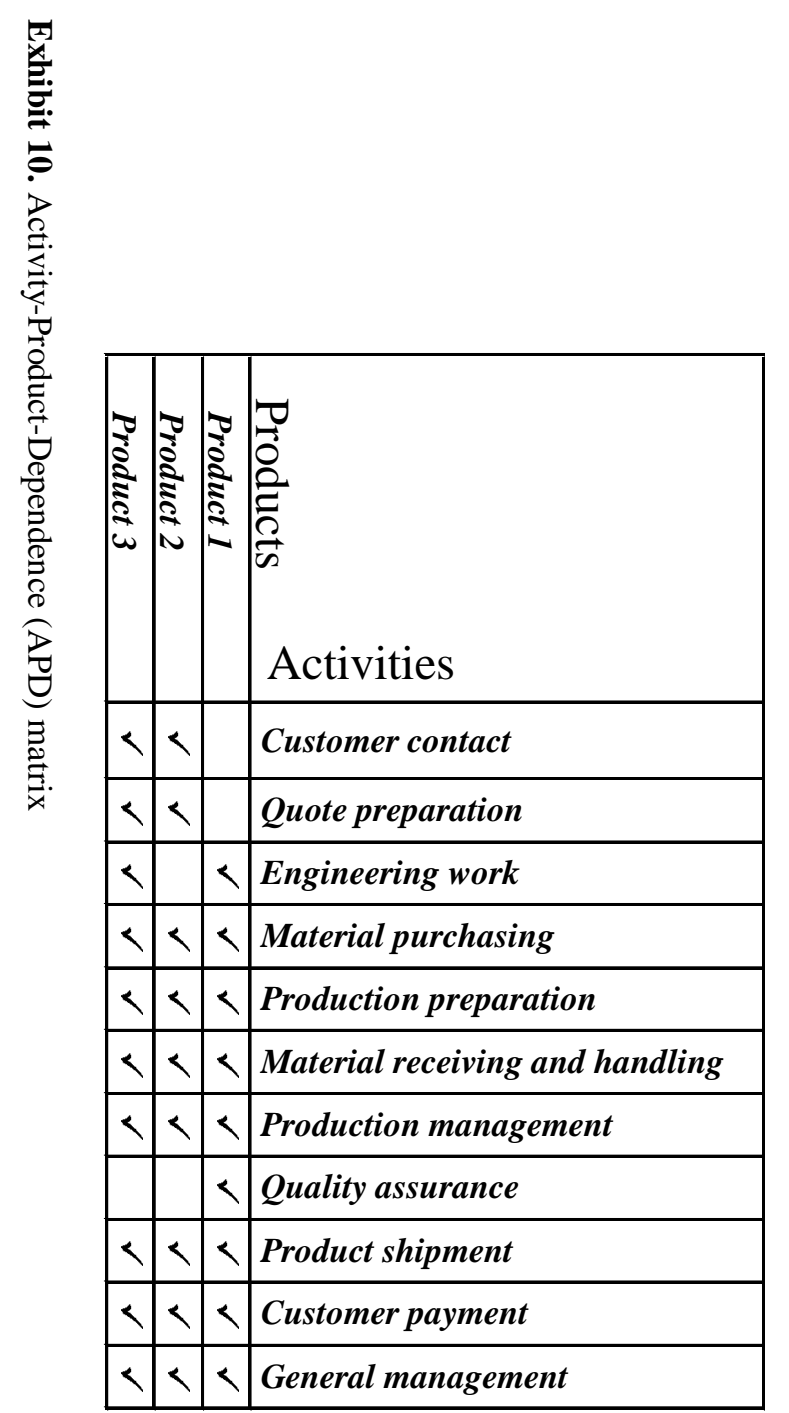

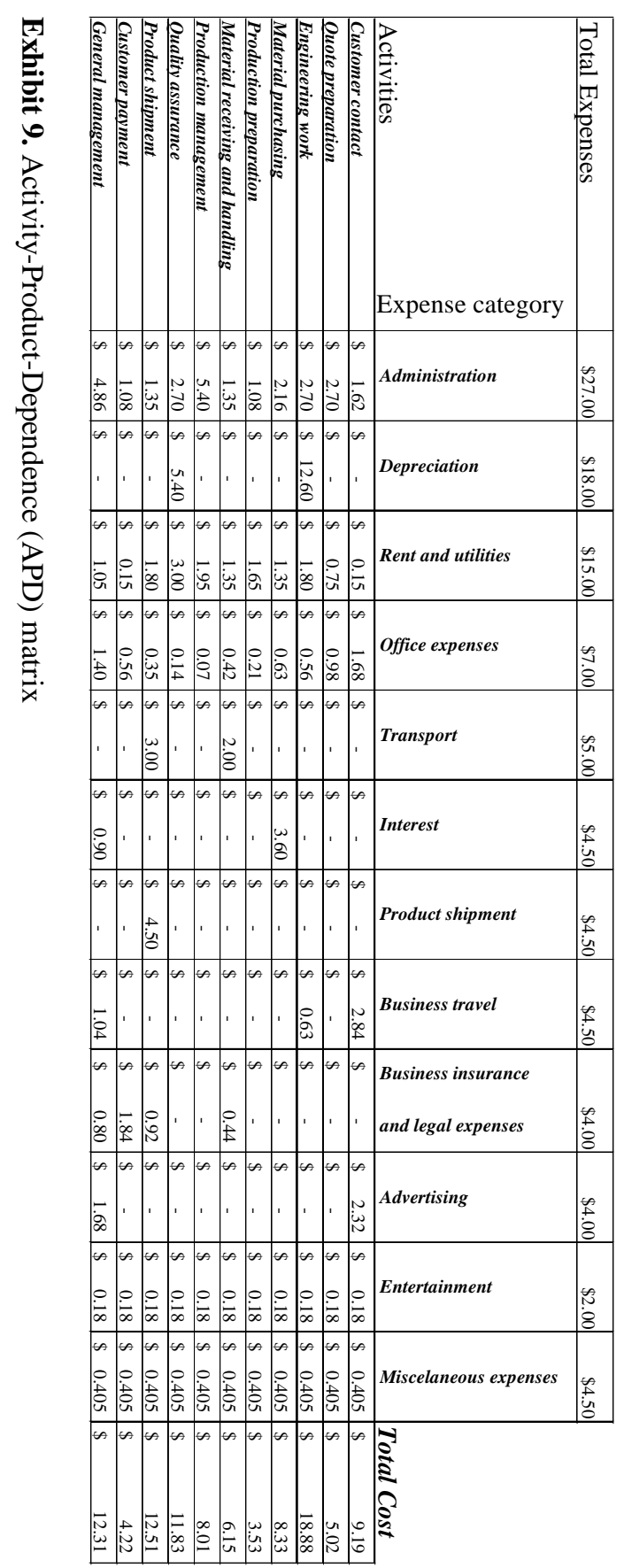


Exhibit 11. Activity-Product-Dependence (APD) matrix $(\$ 10,000)$

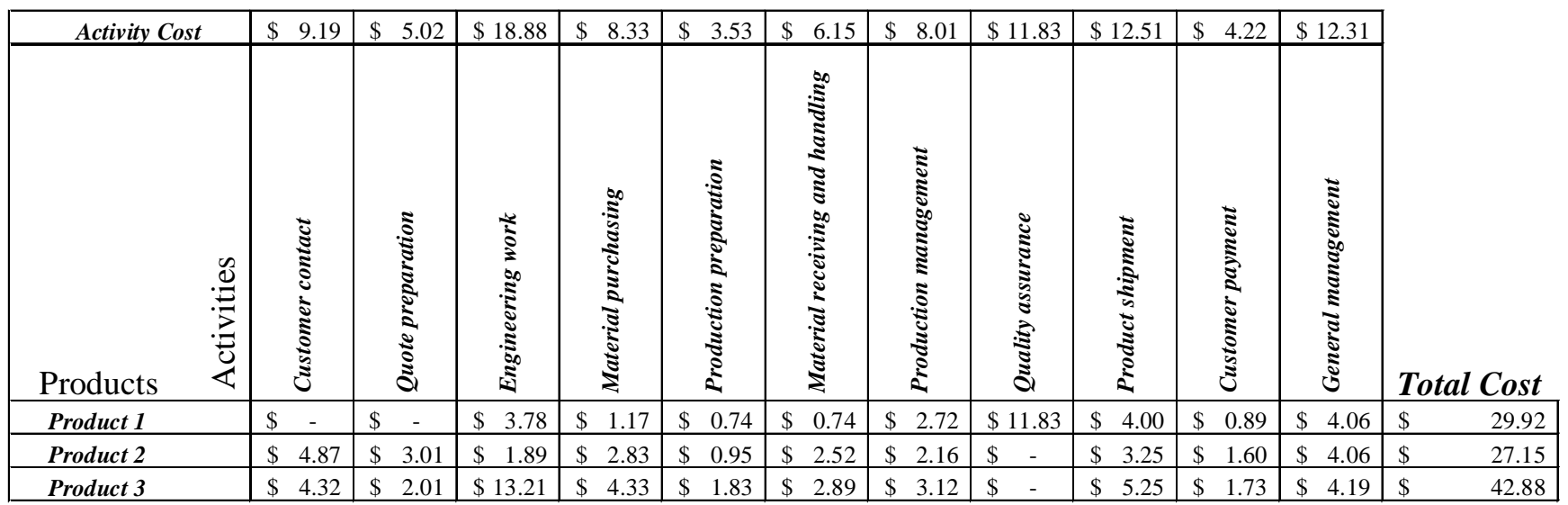

\section{References}

Bharara, A. and Lee, C.Y., "Implementation of an Activity-Based Costing System in a Small Manufacturing Company," International Journal of Production Research, Vol.34, No.4, 1996, pp. 1109-1130.

Cooper, R., "The Two-Stage Procedure in Cost Accounting- Part One," Journal of Cost Management, Vol.1, No.2, (Summer 1987a), pp. 43-51.

Cooper, R., "The Two-Stage Procedure in Cost Accounting- Part Two," Journal of Cost Management, Vol.1, No.3, (Fall 1987b), pp. 39-45.

Cooper, R., "The Rise of Activity-Based Costing- Part One: What is an Activity-Based Cost System?" Journal of Cost Management, Vol.2, No.2 (Summer 1988a), pp.4554.

Cooper, R., "The Rise of Activity-Based Costing- Part Two: When Do I Need an Activity-Based Cost System?" Journal of Cost Management, Vol.2, No.3, (Fall 1988b), pp.41-48.

Cooper, R., "Elements of Activity-Based Costing", Emerging Practices in Cost Management. Boston: Warran Gorham \& Lamont, 1990.

Cooper, R., and Kaplan, R. S., "Measure Cost Right: Make the Right Decisions," Harvard Business Review, September-October 1988, pp. 96-102.

Golden, B. L., Wasil, E. A., and Harker, P. T., The Analytic Hierarchy Process, Applications and Studies, New York: Springer-Verlag, 1989.

Johnson, H. T. and Kaplan, R. S., Relevance lost: The rise and fall of management accounting, Boston: Harvard Business School Press, 1987.
Johnson, H. T., "The Decline of Cost Management: A Reinterpretation of $20^{\text {th }}$-Century Cost Accounting History," Journal of Cost Management, Vol. 1, No.1, (Spring 1987), pp.5-12.

Johnson, H. T., "Activity Management: Reviewing the Past and Future of Cost Management," Journal of Cost Management, Vol.3, No.4 (Winter 1990), pp. 4-7.

Johnson, H. T., "Activity-Based Management: Past, Present, and Future," The Engineering Economist, Vol.36, No.2, (Spring 1991), pp.219-238.

Needy, K. L. and Bidanda, B., “ Activity Based Costing for Small Manufactures- A Field Study," $4^{\text {th }}$ Industrial Engineering Research Conference Proceedings, Nashville, TN, May 24-25, 1995, pp. 628-634.

Saaty, T. L., Decision Making for Leaders, London: Lifetime Learning Publications, 1982.

Turney, P. B., "Using Activity-Based Costing to Achieve Manufacturing Excellence," Journal of Cost Management, Vol.3, No.2, (Summer 1989), pp. 23-31.

Welsh, J. A. and White, J. F., "A Small Business Is not a Little Big Business," Harvard Business Review, JulyAugust 1981, pp 18-32.

\section{About the Authors}

Narcyz Roztocki is an Assistant Professor of Business Administration at the State University of New York (SUNY) at New Paltz. He received his M.S. degree in Mechanical Engineering from the Technical University Hamburg-Harburg, Germany and his Ph.D. in Industrial Engineering from the University of Pittsburgh. His research focus is in the area of Strategic Management, Activity Based Costing, Economic Value Added, Decision Support Tools and Information Systems. He is a member of ASEM and IIE. 
Jorge F. Valenzuela received his B.S. in Electronic Engineering from Northern Catholic University in Chile (1984). He obtained a M.S. degree in Statistics at CIENES and a M.S. degree in Industrial Engineering at Northern Illinois University in 1985 and 1996, respectively. Currently he is a Ph.D. student at the University of Pittsburgh.

Jose D. Porter received his B.S. in Mechanical Engineering from Universidad Autonoma de Nuevo Leon in Mexico in 1991. He obtained a M.S. degree in Manufacturing Systems at I.T.E.S.M. (Mexico) in 1994. Currently he is a Ph.D. candidate at the University of Pittsburgh.

Robin M. Monk received her B.S. in Industrial Engineering from the University of Pittsburgh in 1996. She obtained a M.S. degree in Industrial Engineering at the University of Pittsburgh in 1998. Currently she is working for PPG Industries in Pittsburgh, PA.

Kim LaScola Needy is an Assistant Professor of Industrial Engineering at the University of Pittsburgh. She received her BS and MS degrees in Industrial Engineering from the University of Pittsburgh, and her Ph.D. in Industrial Engineering from Wichita State University. She has obtained nine years of industrial experience at PPG Industries and The Boeing Company. Her research interests include Activity Based Costing, TQM, Engineering Management, and Integrated Resource Management. Dr. Needy is a member of ASEE, ASEM, APICS, IEEE, IIE, SME and SWE. She is a licensed PE in Kansas. 